\title{
Physico-chemical characterization and biometry of fruits of 'pequi' in Western Bahia
}

\author{
Roxana S. M. Nascimento ${ }^{1}$ \& Fabio D. M. Cocozza ${ }^{1}$ \\ ${ }^{1}$ Laboratorio de Sementes/Universidade do Estado da Bahia. Barreiras, BA. E-mail: roxana.mendes@hotmail.com (Autora correspondente); \\ agrobio.alimentos@gmail.com
}

\section{Key words:}

cerrado

postharvest

native fruit tree

Caryocar brasiliense Camb.

\begin{abstract}
A B S T R A C T
In Cerrado, there are numerous native fruit species with potential for use in traditional systems of agricultural production. In this context, the 'pequi' stands out in this biome by its great economic value in Central Brazil. Therefore, this work aimed to study the physical and physicochemical characterization of Pequi fruits in the Western Region of Bahia. Three hundred fruits were sampled from ten matrices which were collected in an area of the municipality of Angical, BA and conducted to the Seed Laboratory of the State University of Bahia - UNEB. For physical evaluations, the fruit weight; longitudinal and transversal diameters of the fruit; total weight of seeds per fruit; pulp weight, peel weight and pulp yield were considered. As for the physico-chemical evaluations, the fruit pulp was subjected to the determinations of $\mathrm{pH}$, the soluble solids (SS), titratable acidity (TA) and the relation between soluble solids and titratable acidity. For the variables, longitudinal and transversal diameters, the pulp weight, peel weight, seed weight, fruit weight and pulp yield, the mean were, respectively, 63.49 and $61.29 \mathrm{~mm}, 12.51,101.91,27.48,114.41 \mathrm{~g}$ and $11.17 \%$. However, with regard to $\mathrm{pH}$, SS, AT and SS/AT, means were $5.32,11.95^{\circ} \mathrm{Brix}, 1.76$ and 11.53 . The results indicated that there are statistically significant differences between all the physical and physico-chemical variables evaluated.
\end{abstract}

\author{
Palavras-chave: \\ cerrado \\ pós-colheita \\ fruteira nativa \\ Caryocar brasiliense Camb.
}

\section{Caracterização físico-química e biometria de frutos de pequizeiro no Oeste da Bahia}

\section{R E S U M O}

No Cerrado existem inúmeras espécies frutíferas nativas que apresentam potencial para a utilização em sistemas tradicionais de produção agrícola. Neste contexto o pequizeiro se destaca neste bioma pelo grande valor econômico na região central do Brasil. Objetivou-se, portanto, com este trabalho, estudar a caracterização física e físico-química de frutos de pequi da região Oeste da Bahia. Foram amostrados 300 frutos de dez matrizes, os quais foram coletados em uma área do município de Angical, BA, e conduzidos ao Laboratório de Sementes da Universidade do Estado da Bahia - UNEB. Foram considerados, para as avaliações físicas, o peso do fruto; diâmetros longitudinal e transversal do fruto; peso total de semente por fruto; peso de polpa, peso de casca e o rendimento de polpa; já para as avaliações físico-químicas a polpa dos frutos foi submetida às determinações do potencial hidrogeniônico $(\mathrm{pH})$; do teor de sólidos solúveis (SS); acidez titulável (AT) e a relação sólidos solúveis e acidez titulável. Para as variáveis diâmetro longitudinal e transversal, peso de polpa, peso de casca, peso de sementes, peso de fruto e rendimento de polpa as médias foram, respectivamente, 63,49 e $61,29 \mathrm{~mm}, 12,51,101,91,27,48,114,41 \mathrm{~g}$ e $11,17 \%$ porém no que se refere aos $\mathrm{pH}$, SS, AT e SS/AT, as médias foram $5,32,11,95^{\circ}$ Brix, 1,76 e 11,53 cujos resultados indicaram haver diferença estatística significativa entre todas as variáveis físicas e físico-químicas avaliadas. 


\section{INTRODUCTION}

There is an enormous potential for exploitation of native fruits in the Brazilian agribusiness sector (Hansen et al., 2013). In Cerrado, there are numerous native fruit species with potential for use in traditional systems of agricultural production. In this context, the pequizeiro (Caryocar brasiliense Camb.) that belongs to Caryocaraceae family stands out in this biome by its great economic value in Central Brazil (Souza et al., 2007).

It is a perennial plant, native from cerrado region (Oliveira et al., 2009). The high presence of this species in this ecosystem, explored in an extractive way, and typical of the region, deserves special attention due to the peculiar characteristics of its fruits as flavor, color and aroma, greatly appreciated by regional population (Souza et al., 2007) for their own consumption, as well as in the commercialization of the fruit in natura (Mariano et al., 2009). The fruit of pequizeiro can be characterized as a drupe with green peel, generally containing between 1 and 4 seeds per fruit, called pyrenes, that are composed of an woody endocarp with numerous thorns, internally containing the seed or an edible almond, and enveloped by a pulp adhered to the kernel of intense yellow color, fleshy and with high oil content, called the inner mesocarp (Soares Júnior et al., 2009; Oliveira et al., 2009).

It is also rich in lipids, especially unsaturated fatty acids such as oleic acid, vitamins A, E, C, and minerals such as phosphorus, potassium and magnesium. In addition, the oil helps to combat free radicals (Lima et al., 2007; Santos et al., 2010).

Due to the exotic flavor and strong and characteristic aroma, the Pequi is widely used by the population of various states of Northern, Northeast and Midwest, as a spice in cooking rice, chicken and meat (Lima et al., 2007). In addition, it is responsible for part of the energy and nutrient intakes for low-income families in rural areas (Oliveira et al., 2009). However, as occurs with some native fruit, little is known about their physical, physico-chemical properties and chemical composition but these informations are resources for the formulation of balanced diets, quality control and development of new products (Oliveira et al., 2009).

Studies by several authors demonstrate the natural variability existing both chemical and physical characteristics of the pequi, reflecting the nutritional factors of the fruit (Silva \& Medeiros Filho, 2006; Vera et al., 2007). This evidence reinforces the need to make the physico-chemical characterization and fruit biometrics in order to obtain subsidies and contribute to the selection of promising individuals to industry and genetic improvement of the species. In addition, physical and physicochemical characterization of fruits provide important information regarding the handling and packaging, and more advanced stage of commercial exploitation, industry, assist in the design of machinery and equipment.

Given the above, the aim of this work was to evaluate the biometric and physico-chemical characteristics of the Caryocar brasiliense fruits in stage of mature maturation.

\section{Material AND Methods}

Fruits were collected in an area of the municipality of Angical, located in the western region of the state of Bahia. The climate of this region, according to Thornthwaite and Mather, is characterized as dry sub-humid - C1d'A '- featuring rainy summer and extremely dry winter, with an annual rainfall of 700-2000 mm (AIBA, 2004), concentrated among the months of October and April, presenting, however, a high probability of dry spells during the rainy season.

Climatic conditions vary, but the highest concentration of rain usually occurs between the months of November and February, with warm rainy summers, harsh climate and low annual rainfall distribution over a short period of the year. The minimum and maximum annual average temperatures are respectively 14 and $34^{\circ} \mathrm{C}$. The relative normal humidity of air in the region varies from $47.1 \%$ in September to $80.3 \%$ in March, reaching a normal annual average that is equivalent to $68 \%$. The region has a luminosity equivalent to $3000 \mathrm{~h} \mathrm{yr}^{-1}$ (AIBA, 2004). It also presents sandy soil and vegetation of the Cerrado.

The collection occurred in december 2009. The specimen from which the fruits were removed had a mean height of 10.00 $\mathrm{m}$. The fruits were collected in the stage of mature maturation (fruits fallen on the ground), originated from ten matrices (Table 1), which were placed in polyethylene bags and taken to the laboratory.

In the laboratory, the biometric evaluations were immediately initiated where 300 mature fruits, healthy, without deformation were randomly selected, because according to Cruz \& Carvalho (2002), are needed at least 100 fruits for conducting the evaluations.

For biometric characterization, it was taken in account the longitudinal and transversal diameters, being considered the largest diameter, measured with a digital caliper (Figure 1); fruit weight in grams, obtained by individual weighing in digital precision balance; seed weight, in grams, using digital precision balance and number of seeds per fruit; pulp weight; peel weight; pulp yield, in percentage that is obtained by dividing the pulp weight and the fruit weight multiplied by 100 (AOAC, 1990).

For physico-chemical analysis, 30 perfect mature fruits were used, randomly collected from a single matrice, immediately after loosen from plant and four quadrants of the specimen were removed, totalizing 300 fruits. After collection, the fruits properly identified were packed in polystyrene boxes and immediately transported to the laboratory.

The fruit pulp was removed after cleaning with the aid of a stainless steel knife, subsequently packaged in polyethylene bags and stored under refrigeration $\left(-18^{\circ} \mathrm{C}\right)$ for physicochemical determinations. The pulp of each matrix was divided into ten equal batches, and each batch was composed

\begin{tabular}{ccc} 
Table 1 . Coordinates of matrices of pequizeiro \\
\hline 1 & Angical & $11^{\circ} 45^{\prime} 81,0^{\prime \prime} / 44^{\circ} 37^{\prime} 25,8^{\prime \prime} / 447 \mathrm{~m}$ \\
2 & Angical & $11^{\circ} 47^{\prime} 03,0^{\prime \prime} / 44^{\circ} 39^{\prime} 28,5^{\prime \prime} / 440 \mathrm{~m}$ \\
3 & Angical & $11^{\circ} 46^{\prime} 58,5^{\prime \prime} / 44^{\circ} 39^{\prime} 26,5^{\prime \prime} / 427 \mathrm{~m}$ \\
4 & Angical & $11^{\circ} 45^{\prime} 48,0^{\prime \prime} / 44^{\circ} 38^{\prime} 08,6^{\prime \prime} / 411 \mathrm{~m}$ \\
5 & Angical & $11^{\circ} 45^{\prime} 48,5^{\prime \prime} / 44^{\circ} 38^{\prime} 07,4^{\prime \prime} / 420 \mathrm{~m}$ \\
6 & Angical & $11^{\circ} 45^{\prime} 48,4^{\prime \prime} / 44^{\circ} 38^{\prime} 06,9^{\prime \prime} / 431 \mathrm{~m}$ \\
7 & Angical & $11^{\circ} 45^{\prime} 47,5^{\prime \prime} / 44^{\circ} 38^{\prime} 06,0^{\prime \prime} / 432 \mathrm{~m}$ \\
8 & Angical & $11^{\circ} 45^{\prime} 73,9^{\prime \prime} / 44^{\circ} 37^{\prime} 18,4^{\prime \prime} / 444 \mathrm{~m}$ \\
9 & Angical & $11^{\circ} 45^{\prime} 73,9^{\prime \prime} / 44^{\circ} 37^{\prime} 18,4^{\prime \prime} / 444 \mathrm{~m}$ \\
10 & Angical & $11^{\circ} 45^{\prime} 78,8^{\prime \prime} / 44^{\circ} 37^{\prime} 24,1^{\prime \prime} / 445 \mathrm{~m}$ \\
\hline
\end{tabular}


A.

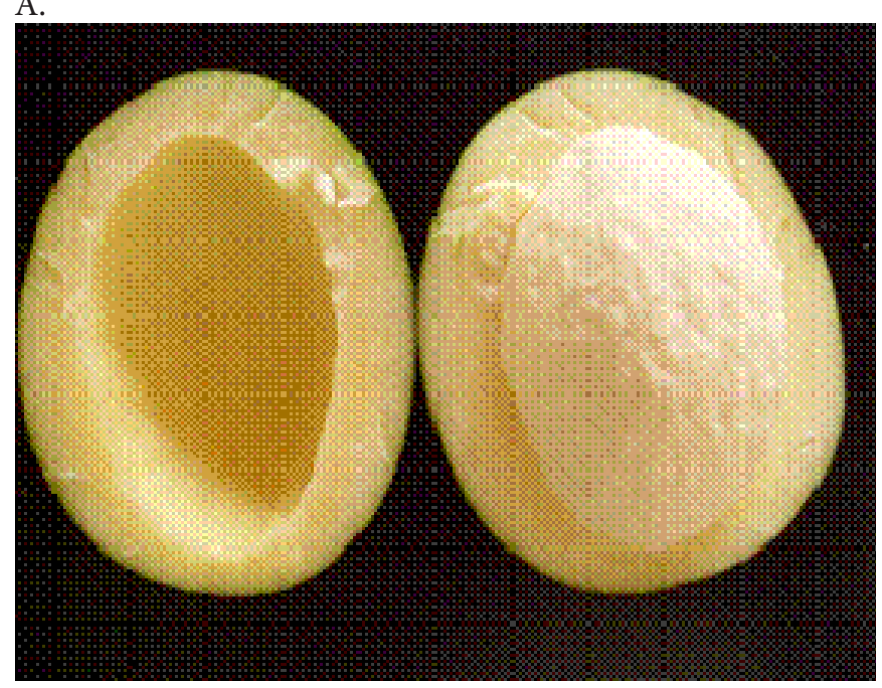

C.

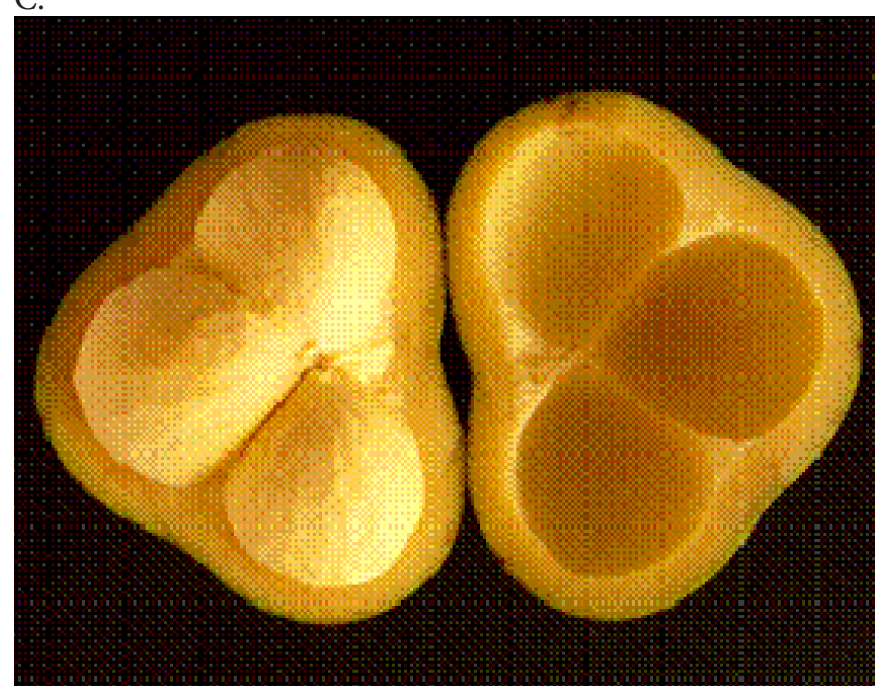

B.

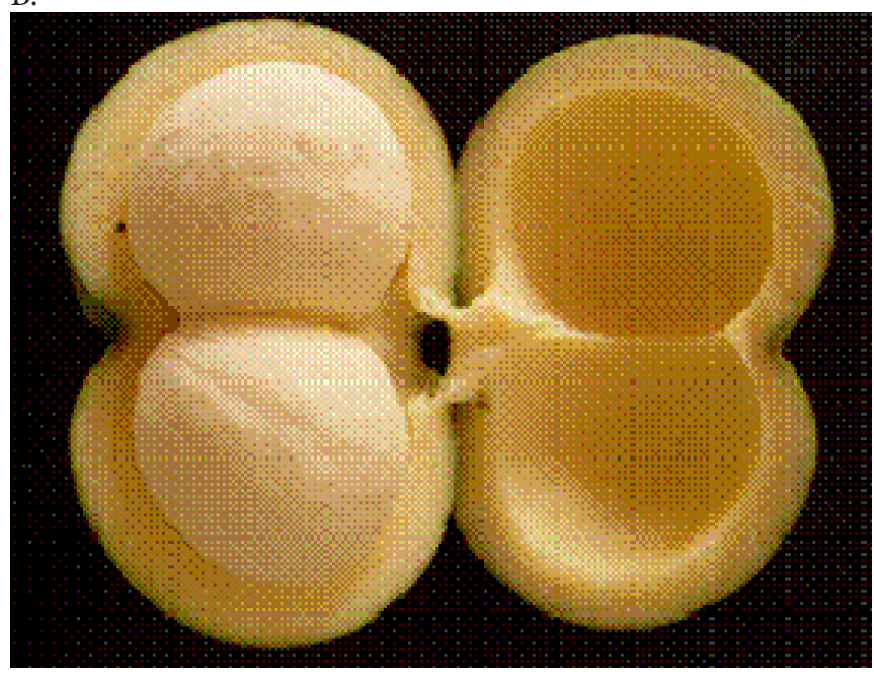

D.

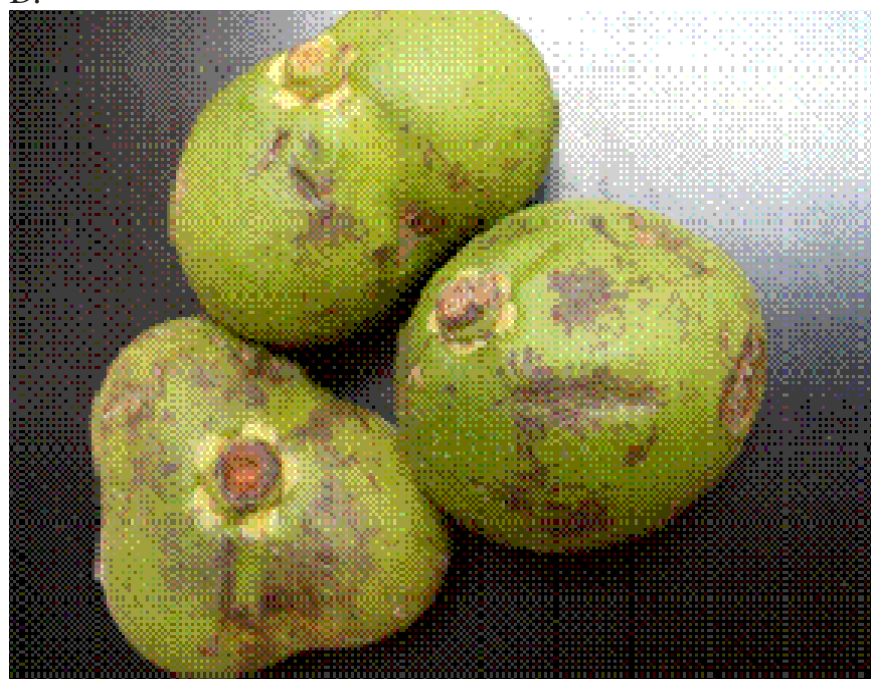

Figure 1. Fruit with a seed (A); fruit with two seeds (B); fruit with three seeds (C) and - fruits (D)

of three fruit pulps. The batches represented the repetitions and the matrices were considered as treatments.

After thawing in the refrigerator, the pulp was subjected to the determinations of the hydrogen potential $(\mathrm{pH})$ by potentiometric method at $\mathrm{pH}$ meter with the aid of a digital meter, calibrating the potentiometer through the buffer solutions ( $\mathrm{pH} 4.0$ and 7.0); of the soluble solids (SS) which was determined by direct reading on digital refractometer and expressed in Brix (AOAC, 1990); of titratable acidity (TA) which was held in the presence of phenolphthalein and determined by titration with standardized solution of sodium hydroxide $(\mathrm{NaOH}) 0.1$ $\mathrm{N}$, expressing the final results in percentage of citric acid in accordance with the Analytical Standards of IAL (1985); and soluble solid and titratable acidity (SS/TA - Ratio).

It was adopted a completely experimental design, with 30 repetitions for biometric analysis and ten repetitions for physico-chemical analysis, and the data subjected to analysis of variance using the $\mathrm{F}$ test and the means were compared by Tukey test at $5 \%$ probability.

\section{Results AND Discussion}

According to the results regarding the biometric evaluations (Table 2), the longitudinal diameter of the fruits of Caryocar brasiliense showed a variation between 58.51 and $72.58 \mathrm{~mm}$ but the transversal diameter showed a variation between 56.08 and $69.82 \mathrm{~mm}$, slightly lower than those values reported in Silva \& Medeiros Filho (2006), which studied the morphology of the fruit Caryocar coriaceum and showed a variation in longitudinal diameter of 5.8 to $7.4 \mathrm{~cm}$ and the transversal diameter ranged between 5.7 and $7.3 \mathrm{~cm}$.

However, a study of Vera et al. (2007) found a variation of 5.24 to $6.17 \mathrm{~cm}$ for the transversal and longitudinal diameters, evaluating the physical and chemical characteristics of the fruits of pequizeiro. The overall average in the longitudinal diameter was $63.49 \mathrm{~mm}$ and CV $13.50 \%$, whereas the overall mean of transversal diameter was 61.29 and CV 5.64\%. Morphological characterization of fruits can provide information on the handling and packaging of the pequi, and more advanced stage of commercial and industrial exploitation, assisting in the design of machinery and equipment.

With respect to the fruit weight there was a variation of 83.90 to $158.17 \mathrm{~g}$, closer values to those reported by studies of Vera et al. (2007) in which the fruit weight of this species had values of 103.55 and $177.93 \mathrm{~g}$. However, Correa et al. (2008) observed a variation of 46.93 to $165.16 \mathrm{~g}$ of the pequi fruits in different municipalities of the state of Goiás. The overall mean and CV were, respectively, $114.41 \mathrm{~g}$ and $23.29 \%$. Silva 
Table 2. Physical characteristics of the fruits of matrices of 'pequi' (Caryocar brasiliense)

\begin{tabular}{|c|c|c|c|c|c|c|c|c|}
\hline \multicolumn{2}{|c|}{ Number } & \multicolumn{3}{|c|}{ Diameter (mm) } & \multicolumn{3}{|c|}{ Weight (g) } & \multirow{2}{*}{$\begin{array}{l}\text { Yield\% } \\
\text { (pulp) }\end{array}$} \\
\hline Matriz & Fruits & Long. & Trans. & Pulp & Seeds & Fruit & Peel & \\
\hline 1 & 30 & $62,54 \mathrm{bcd}$ & $68,63 \mathrm{a}$ & $12,64 \mathrm{~cd}$ & $35,26 \mathrm{a}$ & $142,39 a b$ & $129,72 a b$ & 9,03 de \\
\hline 2 & 30 & $58,51 \mathrm{~d}$ & $57,05 \mathrm{C}$ & $8,16 \mathrm{e}$ & 23,37 de & $97,41 \mathrm{de}$ & 89,24 def & $8,25 \mathrm{e}$ \\
\hline 3 & 30 & 61,44 bcd & $62,83 b$ & $12,33 \mathrm{~cd}$ & $26,62 \mathrm{~cd}$ & $109,83 d$ & 97,60 cde & $11,15 \mathrm{~cd}$ \\
\hline 4 & 30 & $72,58 \mathrm{a}$ & $69,82 \mathrm{a}$ & 14,18 bc & $33,36 a b$ & $158,17 \mathrm{a}$ & $143,99 \mathrm{a}$ & $9,00 \mathrm{de}$ \\
\hline 5 & 30 & $65,88 \mathrm{abc}$ & $61,63 b$ & $16,83 \mathrm{ab}$ & $28,54 \mathrm{bcd}$ & $107,02 \mathrm{~d}$ & 90,19 def & $16,22 \mathrm{a}$ \\
\hline 6 & 30 & $59,96 \mathrm{~cd}$ & $56,37 \mathrm{c}$ & $13,03 \mathrm{~cd}$ & 25,49 cde & 96,67 de & 83,64 ef & $13,51 \mathrm{~b}$ \\
\hline 7 & 30 & $61,60 \mathrm{bcd}$ & $56,39 \mathrm{c}$ & $8,25 \mathrm{e}$ & $21,28 \mathrm{e}$ & $98,12 \mathrm{de}$ & 89,87 def & $8,63 \mathrm{e}$ \\
\hline 8 & 30 & $60,25 \mathrm{~cd}$ & $56,08 \mathrm{C}$ & $11,92 \mathrm{~cd}$ & 25,62 cde & $83,90 \mathrm{e}$ & $71,98 f$ & $14,35 a b$ \\
\hline 9 & 30 & $63,85 \mathrm{bcd}$ & $61,07 \mathrm{~b}$ & 10,22 de & 26,52 cde & $116,26 \mathrm{~cd}$ & $106,05 \mathrm{~cd}$ & $8,47 \mathrm{e}$ \\
\hline \multirow[t]{3}{*}{10} & 30 & $68,33 \mathrm{ab}$ & $63,01 \mathrm{~b}$ & $17,54 \mathrm{a}$ & 28,75 bc & $134,33 \mathrm{bc}$ & $116,79 \mathrm{bc}$ & $13,11 b c$ \\
\hline & $M G$ & 63,49 & 61,29 & 12,51 & 27,48 & 114,41 & 101,91 & 11,17 \\
\hline & CV\% & 13,50 & 5,64 & 31,72 & 23,33 & 23,29 & 23,51 & 24,84 \\
\hline
\end{tabular}

Means followed by different letters in columns differ by Tukey test at 0.05 level of probability

et al. (2012) observed a variation of 83.05 to $259.98 \mathrm{~g}$ between the mean matrices evaluated in two populations in the state of Minas Gerais.

The fruit weight is an important characteristic for the marketing of fruit in natura, since the fruits which have larger size are heavier and thus are of most interest (Chitarra \& Chitarra, 2005). So, the matrices 1, 4, 9 and 10 stood out in relation to the fruit weight (Table 2 ).

As Table 2 shows, the seeds weight ranged from 21.28 to $35.26 \mathrm{~g}$, presenting, however, an overall average of $27.48 \mathrm{~g}$ and CV of $23.33 \%$. Vera et al. (2007) reported values of $2.67 \mathrm{~g}$ and $3.22 \mathrm{~g}$ for the total weight of almonds per fruit, lower than those found in the present study. Also according to Chitarra \& Chitarra (2005), the seeds weight per fruit is also a very important physical characteristic for marketing, since this characteristic may influence the yield of fruits, especially those intended for the manufacture of products.

So the matrices 2 and 7, showed the lowest seed weight per fruit, since the number of seeds per fruit ranged from 1 to 3 . However, Correa et al. (2008) observed for the number of seeds a variation between the fruits of 1.08 to 2.50 .

With respect to the pulp weight, the lower value observed was $8.16 \mathrm{~g}$ and the largest was $17.54 \mathrm{~g}$, and the overall average of $12.51 \mathrm{~g}$ and $\mathrm{CV}$ of $31.72 \%$. The peel had as the general average value of $101.91 \mathrm{~g}$ and $\mathrm{CV}$ of $23.51 \%$, however, showed as the maximum value and minimum value 129.72 and $71.98 \mathrm{~g}$, values that corroborate with those reported by Vera et al. (2007) in a study with pequis whose maximum values for the weight of pulp and peel were respectively 3.98 and $139.36 \mathrm{~g}$. Silva et al. (2012) found average values by matrix for the variable average pulp weight ranging between 5.38 and $14.25 \mathrm{~g}$, and for the peel weight the average found between the matrices ranged from 61.57 to $220.00 \mathrm{~g}$.

The pulp yield showed a variation between 8.25 and $14.35 \%$. The pulp yield refers to the quality and quantity of the raw material, so it is a characteristic of fundamental importance to the industry (Chitarra \& Chitarra, 2005). Thus, matrices which have stood out in this feature were matrices 5, 6, 8 and 10 , with the highest pulp yields.

Table 3 shows a positive correlation for all physical variables of the fruits of pequizeiro, with the exception of the correlations of Fruit Weight X Number of Seeds/Fruit, Average Weight of Seeds/Fruit X Number of Seeds/Fruit, Number of Seeds/ Fruit X Longitudinal Diameter, Number of Seeds/Fruits X
Transversal Diameter, Number of Seeds/Fruits X Peel, being that most of the variables showed no significant correlation. The highest values observed were for the Fruit Weight X Longitudinal Diameter (0.94), Fruit Weight X Peel Weight (0.99) and Average Weight of Seeds/Fruit X Longitudinal Diameter (0.93) showing, therefore, that the value of a variable is directly proportional to the value of the other.

The results related to the physico-chemical evaluations are shown on Table 4 . Acidity presented a mean value of $1.76 \%$, higher than the $0.28 \%$ value found by Sousa et al. (2012) and $0.042 \%$ found by Arévalo-Pinedo et al. (2010). But being the maximum value $4.29 \%$ and the minimum value $0.49 \%$ found in this work.

Regarding the $\mathrm{pH}$ of the fruits of pequizeiro, it differs statistically in most of the evaluated data, presenting as minimum value 4.33 and maximum value 6.71 . The overall average of $\mathrm{pH}$ was 5.32, lower than that found by ArévaloPinedo et al. (2010), whose $\mathrm{pH}$ value of pequis was 7.36. The $\mathrm{pH}$ is a characteristic that is related to food quality and safety,

Table 3. Correlation between the physical variables of the fruits of matrices of 'pequi' (Caryocar brasiliense)

\begin{tabular}{|c|c|c|}
\hline Correlation & $\begin{array}{l}\text { Correlation } \\
\text { coefficient (r) }\end{array}$ & Significance \\
\hline Fruit x Average Weight of Seeds/Fruit & 0,86 & ** \\
\hline Fruit Weight X Pulp & 0,44 & ns \\
\hline Fruit Weight $x$ Number of Seeds/Fruits & $-0,20$ & ns \\
\hline Fruit Weight x Longitudinal Diameter & 0,94 & ** \\
\hline Fruit Weight $x$ Transversal Diameter & 0,79 & ** \\
\hline Fruit Weight $x$ Peel Weight & 0,99 & ** \\
\hline Average Weight of Seeds/Fruit x Peel & 0,56 & ns \\
\hline $\begin{array}{l}\text { Average Weight of Seeds/Fruit x Number of } \\
\text { Seeds/Fruits }\end{array}$ & $-0,31$ & ns \\
\hline $\begin{array}{l}\text { Average Weight of Seeds/Fruit x Longitudinal } \\
\text { Diameter }\end{array}$ & 0,93 & ** \\
\hline $\begin{array}{l}\text { Average Weight of Seeds/Fruit x Transversal } \\
\text { Diameter }\end{array}$ & 0,61 & ns \\
\hline Average Weight of Seeds/Fruit x Peel & 0,82 & ** \\
\hline Peel x Number of Seeds/Fruits & 0,12 & ns \\
\hline Pulp x Longitudinal Diameter & 0,48 & ns \\
\hline Pulp x Transversal Diameter & 0,64 & * \\
\hline Pulp x Peel & 0,33 & ns \\
\hline $\begin{array}{l}\text { Number of Seeds/Fruits x Longitudinal } \\
\text { Diameter }\end{array}$ & $-0,36$ & ns \\
\hline Number of Seeds/Fruits $x$ Transversal Diameter & $-0,18$ & ns \\
\hline Number of Seeds/Fruits $\times$ Peel & $-0,23$ & $\mathrm{~ns}$ \\
\hline Longitudinal Diameter x Transversal Diameter & 0,73 & * \\
\hline
\end{tabular}


Table 4. Physico-chemical characteristics of the fruits of 'pequi' (C. brasiliense)

\begin{tabular}{|c|c|c|c|c|}
\hline Matrices & pH & SS ("Brix) & $\begin{array}{c}\text { AT } \\
\text { (\% ác. cítrico) }\end{array}$ & SS/AT - Ratio \\
\hline 1 & $4,33 \mathrm{e}$ & $9,80 \mathrm{c}$ & $3,66 \mathrm{a}$ & $2,85 d$ \\
\hline 2 & $6,71 \mathrm{a}$ & $12,10 a b c$ & $0,49 \mathrm{e}$ & $24,82 \mathrm{a}$ \\
\hline 3 & $5,09 \mathrm{c}$ & $12,00 \mathrm{bc}$ & $1,57 b c$ & $8,27 \mathrm{bcd}$ \\
\hline 4 & $5,44 \mathrm{C}$ & $11,20 \mathrm{bc}$ & 1,31 bcde & 10,77 bcd \\
\hline 5 & $6,24 a b$ & $14,20 a b$ & 0,98 cde & $17,29 a b$ \\
\hline 6 & $5,18 \mathrm{c}$ & $10,60 \mathrm{bc}$ & $1,45 \mathrm{bcd}$ & $7,80 \mathrm{~cd}$ \\
\hline 7 & $6,14 b$ & $9,80 \mathrm{c}$ & $0,63 \mathrm{de}$ & 16,16 abc \\
\hline 8 & 4,57 de & $10,00 \mathrm{bc}$ & $1,98 \mathrm{~b}$ & $5,80 \mathrm{~d}$ \\
\hline 9 & $5,03 \mathrm{~cd}$ & $13,40 a b c$ & 1,21 bcde & $17,21 a b$ \\
\hline 10 & $4,53 \mathrm{de}$ & $16,40 \mathrm{a}$ & $4,29 \mathrm{a}$ & $4,36 \mathrm{~d}$ \\
\hline$M G$ & 5,32 & 11,95 & 1,76 & 11,53 \\
\hline CV \% & 6,74 & 24,96 & 17,42 & 26,57 \\
\hline
\end{tabular}

Means followed by different letters in columns differ by Tukey test at 0.05 level of significance

presenting, however, a range determined by legislation to promote the conservation of pulp, preventing the growth of yeasts, according to Brasil (1999).

Thus, the Pequi differs from most tropical fruits with regard to the characteristics of industrial interest by having a $\mathrm{pH}$ that classifies it as a non-acid food, enabling for the development of pathogenic microorganisms such Clostridium botulinum (Nascimento et al., 2011).

The average value of SS $\left(11.95^{\circ}\right.$ Brix $)$ observed in this study was quite contrasting when compared to that found by Sousa et al. (2012), $4.50^{\circ}$ Brix. Taking into account this variable, all matrices are conducive for processing and consumption in natura, because from the commercial point of view the fruits with higher soluble solids contents are preferred (Pereira et al., 2000).

The results concerning the ratio SS/TA indicate that the minimum value of the ratio SS/TA was 2.85 and the maximum value was 17.29 , but the overall average was 11.53 . The SS/TA ratio provides a good assessment of fruit flavor, being more representative that isolated measurement of sugars and acidity (Pinto et al., 2003).

For the physico-chemical characteristics of the fruits of pequizeiro, could be observed that the correlations were not significant, as shown in Table 5. However, the correlations were positive, except for the correlation of $\mathrm{pH} \times$ Acidity $(-0.8011)$, which means that the increase of the $\mathrm{pH}$ is inversely proportionate to the increase of acidity.

The variation in the data of fruits of the evaluated matrices was expected, according to Nascimento et al. (2011) because plants are not yet domesticated. According to Silva et al. (2012) the non-domesticated species show great variation between matrices for some physical characteristics in fruits such as size, color, number of seeds per fruit, weight of the seeds and pulp. Thus, the evaluation of these variables in different matrices of different populations is important for its improvement.

The identification of genetic material that besides of being productive shows superior quality for industrial use

Table 5. Correlation between the physico-chemical characteristics of the fruits of matrices of 'pequi' (C. brasiliense)

\begin{tabular}{ccc}
\hline Correlation & Correlation coefficient (r) & Significance \\
pH x Brix & 0,0165 & ns \\
pH x Acidity & $-0,8011$ & ns \\
Brix x Acidity & 0,2925 & ns \\
\hline
\end{tabular}

and/or consumption in natura is crucial for the formation of commercial plantations. However, when it was worked with perennial species such as the pequizeiro, the time to complete one cycle of selection is the main limitation of genetic breeding programs (Silva et al., 2012).

\section{Conclusions}

1. Physical evaluations demonstrate that the studied matrices showed statistically significant differences on all the variables assessed, mainly in relation to measures of weight and size, which shows that the population has high genetic potential for conservation of germplasm and the seed collection.

2. The physico-chemical analysis showed a significant variation between the matrices relative to the $\mathrm{pH}, \mathrm{TA}, \mathrm{SS}$ and SS/TA, which reinforces the indication of the matrices for studies of genetic improvement.

3. Knowledge of the physical and physico-chemical properties of the fruit is of fundamental importance to assess the availability of nutrients and the best features for processing. The identification of genetic materials, and productive, presenting top quality for industrial use and/or fresh consumption is crucial for formation of commercial plantations and breeding studies.

\section{ACKNOWLeDgments}

University of State of Bahia - UNEB and Foundation for Research Support of the State of Bahia - FAPESB for grant of the scholarship to the first author.

\section{Literatura Citada}

AIBA - Associação dos Irrigantes do Oeste da Bahia. Região Oeste da Bahia - safra 2004. Informativo.

AOAC - Association of Official Agricultural Chemists. Official methods of analysis of the association of agricultural chemists, 11.ed., Washington: AOAC, 1990. 1141p.

Arévalo-Pinedo, A.; Maciel, V. B. V.; Carvalho, K. M.; Coelho, A. F. S.; Giraldo-Zuñiga, A. D.; Arévalo, Z. D. De S.; Alvim, T. da C. Processamento e estudo da estabilidade de pasta de pequi (Caryocar brasiliense). Ciência e Tecnologia de Alimentos, v.30, p.664-668, 2010. http://dx.doi.org/10.1590/S010120612010000300015

Brasil. Ministério da Agricultura e do Abastecimento. Instrução Normativa $\mathrm{n}^{\circ} 122$, de 10 de setembro de 1999. Diário Oficial da República Federativa do Brasil, Brasília, 13 de set. de 1999. Seção $1,4 \mathrm{p}$.

Chitarra, M. I. F.; Chitarra, A. B. Pós-colheita de frutos e hortaliças: Fisiologia e manuseio. Lavras: ESAL/FAEPE, 2005. 320p.

Correa, G. C.; Naves,R. V.; Rocha, M. R.; Chaves, L. J.; Borges, J. D. Determinações físicas em frutos e sementes de baru (Dipteryx alata Vog.), cajuzinho (Anacardium othonianum Rizz.) e pequi (Caryocar brasiliense Camb.), visando ao melhoramento genético. Bioscience Journal, v.24, p.42-47, 2008.

Cruz, E. D.; Carvalho, J. E. U. Biometria de frutos e germinação de sementes de Couratari stellata A. C. Smith (Lecythidaceae). Acta Amazonica, v.33, p.381-388, 2002. http://dx.doi.org/10.1590/ S0044-59672003000300004 
Hansen, O. A. de S.; Cardoso, R. L.; Fonseca, A. A. O.; Viana, E. de S.; Hansen, D. de S.; Barreto, N. S. E. Desenvolvimento e avaliação da estabilidade de néctar de mangaba. Magistra, v.25, p.148-156, 2013.

IAL - Instituto Adolfo Lutz. Métodos físico-químicos para análise de alimentos. 4.ed. Brasília: Ministério da Saúde, Agência Nacional de Vigilância Sanitária, 1985. 1000p.

Lima, A. de; Silva, A. M. de O. E; Trindade, R. A.; Torres, R. P.; Mancini Filho, J. Composição química e compostos bioativos presentes na polpa e na amêndoa do pequi (Caryocar brasiliense, Camb.). Revista Brasileira de Fruticultura, v.29, p.695-698, 2007. http:// dx.doi.org/10.1590/S0100-29452007000300052

Mariano, R. G. B.; Couri, S.; Freitas, S. P. Enzymatic technology to improve oil extraction from Caryocar brasiliense Cam. (pequi) pulp. Revista Brasileira de Fruticultura, v.31, p.637-643, 2009. http://dx.doi.org/10.1590/S0100-29452009000300003

Nascimento, R. S. M.; Cardoso, J. A.; Oliveira, L. D. de; Oliveira, J. da S.; Cocozza, F. del M.; Cortes, J. M. Caracterização físico-química de muricis (Byrsonima verbascifolia Rich. ex A. Juss.) produzidos na região Oeste da Bahia. Magistra, v.23, p.236-242, 2011.

Oliveira, M. E. B,; Guerra, N. B.; Maia, A. H. N.; Alves, R. E.; Xavier, D. S.; Matos, M. S. Caracterização física de frutos do pequizeiro nativos da chapada do Araripe-CE. Revista Brasileira de Fruticultura, v.31, p.1196-1201, 2009. http://dx.doi.org/10.1590/ S0100-29452009000400038

Pereira, M. C. T.; Salomão, L. C. C.; Mota, W. F. da; Vieira, G. Atributos físicos e químicos de frutos de oito clones de jabuticabeiras. Revista Brasileira de Fruticultura, v.22, n. especial, p.16-21, 2000.

Pinto W. S.; Dantas, A. C. V. L.; Fonseca, A. A. O.; Ledo, C. A. S.; Jesus, S. C.; Calafange, P. L. P.; Andrade, E. M. Caracterização física, físico-química e química de frutos de genótipos de cajazeiras. Pesquisa Agropecuária Brasileira, v. 38, p.1059-1066, 2003. http:// dx.doi.org/10.1590/S0100-204X2003000900006
Santos, P. dos; Porto, A. G.; Silva, F. S. da; Furtado, G. de F. Avaliação físico-química e sensorial do pequi (Caryocar brasiliensis Camb.) submetido à desidratação. Revista Brasileira de Produtos Agroindustriais, v.12, p.115-123, 2010. http://dx.doi. org/10.15871/1517-8595/rbpa.v12n2p115-123

Silva, F. H. de L. e; Fernandes, J. S. C.; Esteves, E. A.; Titon, M.; Santana, R. C. Populações, matrizes e idade da planta na expressão de variáveis físicas em frutos do pequizeiro. Revista Brasileira de Fruticultura, v.34, p.806-813, 2012. http://dx.doi.org/10.1590/ S0100-29452012000300021

Silva, M. A. P. da; Medeiros Filho, S. Morfologia de fruto, semente e plântula de piqui (Caryocar coriaceum Wittm.). Ciência Agronômica, v.37, p.320-325, 2006.

Soares Júnior. MS., Reis, R. C.; Bassinello, P. Z.; Lacerda, D. B. C.; Koakuzu, S. N.; Caliari, M. Qualidade de biscoitos formulados com diferentes teores de farinha de casca de pequi. Pesquisa Agropecuária Tropical, v.39, p.98-10. 2009.

Sousa, F. C. de; Silva, L. M. de M.; Sousa, E. P. de; Lima, A. K. V. de O.; Figueiredo, R. M. F. de. Parâmetros físicos e físico-químicos da polpa de pequi. Revista Verde de Agroecologia e Desenvolvimento Sustentável, v.6, p.12-15, 2012.

Souza, E. C.; Vilas-Boas; E. V. de B.; Vilas-Boas, B. M.; Rodrigues, L. J.; Paula, N. R. F. Qualidade e vida útil de pequi minimamente processado armazenado sob atmosfera modificada. Revista Ciência e Agrotecnologia, v.31, p.1811-1817, 2007. http://dx.doi. org/10.1590/S1413-70542007000600031

Vera, R.; Souza, E. R. B. De; Fernandes, E. P.; Naves, R. V.; Júnior, M. S. S.; Caliari, M.; Ximenes, P. A. Caracterização física e química de frutos do pequizeiro (Caryocar brasiliense Camb.) oriundos de duas regiões no estado de Goiás, Brasil. Pesquisa Agropecuária Tropical, v.37, p.93-99, 2007. 